\title{
PEMANFAATAN BIOCHAR SEKAM DAN KOMPOS JERAMI PADI TERHADAP PERTUMBUHAN DAN PRODUKSI PADI (Oryza sativa) PADA TANAH ORDO ULTISOL
}

\author{
WELLY HERMAN ${ }^{1 *}$ dan ELARA RESIGIA ${ }^{1}$ \\ ${ }^{\mathbf{1}}$ Program Studi Agroteknologi, Fakultas Pertanian, Universitas Tamansis wa \\ *Email : welly herman@yahoo.com
}

\begin{abstract}
ABSTRAK
Tujuan penelitian ini adalah (1) untuk mengetahui pengaruh penggunaan biochar sekam padi dan kompos jerami padi terhadap pertumbuhan dan produksi padi (Oryza sativa) dan (2) untuk mengetahui kemampuan biochar sekam dan kompos jerami padi dalam menyediakan hara pada tanah ordo Ultisol. Penelitian dilaksanakan pada Februari- Juli 2018 di Kenagarian Sungai Abang, Kecamatan Lubuk Alung, Kabupaten Padang Pariaman. Penelitian menggunakan rancangan acak kelompok (RAK) yang terdiri dari 5 taraf perlakuan yaitu $0 \%$ Biochar sekam padi $+0 \%$ Kompos jerami padi, $100 \%$ Biochar sekam padi $+0 \%$ Kompos jerami padi, $75 \%$ Biochar sekam padi $+25 \%$ Kompos jerami padi, $50 \%$ Biochar sekam padi $+50 \%$ Kompos jerami padi dan $25 \%$ Biochar sekam padi $+75 \%$ Kompos jerami padi. Pengamatan dilakukan terhadap tanah dan tanaman yang meliputi analisis tanah awal yaitu sebelum perlakuan diberikan, analis is tanah setelah inkubasi, dan analisis tanah akhir ( $\mathrm{pH}, \mathrm{N}$-total, $\mathrm{P}$-total, K-dd, Ca-dd, Mg-dd dan Sulfur) dan pengamatan tanaman meliputi tinggi tanaman, jumlah anak total, jumlah anakan produktif dan bobot gabah per hektar. Dari penelitian yang te lah dilakukan dapat disimpulkan (1) penggunaan biochar dan kompos jerami padi mempengaruhi pertumbuhan dan produksi tanaman padi yang terlihat pada perlakuan $75 \%$ Biochar sekam padi $+25 \%$ Kompos Jerami dengan jumlah anakan produktif sebanyak 29 anakan dan produksi tanaman padi sebanyak 8,238 ton/ha dan (2) penggunaan biochar sekam dan kompos jerami padi mampu menyediakan hara pada tanah ordo Ultisol yang ditunjukkan dengan meningkatnya $\mathrm{pH}, \mathrm{N}, \mathrm{P}, \mathrm{K}$, $\mathrm{Ca}, \mathrm{Mg}$ dan $\mathrm{S}$.
\end{abstract}

Kata kunci : Biochar Sekam Padi; Kompos Jerami Padi; Ultisol

\begin{abstract}
The aim of this study were (1) to determine the effect of rice husk biochar and rice straw compost on growth and production rice (Oryza sativa) and (2) to determine the ability of rice husk biochar and rice straw compost in providing nutrients to Ultisol. The research was carried out February - July 2018 in Sungai Abang Village, Lubuk Alung Regency, Padang Pariaman. Research applied Random Group Design with 5 treatment : 0\% Rice husk biochar + 0\% Rice straw compost, 100\% Rice husk biochar + 0\% Rice straw compost, 75\% Rice husk biochar + $25 \%$ Rice straw compost, $50 \%$ Biochar rice husk $+50 \%$ Rice straw compost and $25 \%$ Rice husk biochar $+75 \%$ Rice straw compost. Observations were made on soil and crops including initial soil analyzes ie before treatment was given, soil analysis after incubation, and final soil analysis ( $\mathrm{pH}, \mathrm{N}$-total, P-available, $\mathrm{K}-\mathrm{dd}, \mathrm{Ca}-\mathrm{dd}, \mathrm{Mg}$-dd and Sulfur) and plant observations include plant height, the productive of tiller, total of tiller and weight of grain per hectare. From the research that has been done can be concluded (1) the use of rice husk biochar and rice straw compost affect the growth and production of rice plants seen in the treatment of $75 \%$ rice husk biochar $+25 \%$ Rice Straw rice husk biochar with the number of productive tillers of 29 tillers and production of rice plants as much as 8,238 tons / ha and (2) the use of rice husk
\end{abstract}


biochar and rice straw compost is able to provide nutrients in Ultisol indicated by increasing $\mathrm{pH}, \mathrm{N}, \mathrm{P}, \mathrm{K}, \mathrm{Ca}, \mathrm{Mg}$ and $\mathrm{S}$.

Keyword : Rice Husk Biochar; Rice Straw compost; Ultisol

Diterima: 5 Juli 2018 disetujui : 23 Juli 2018

\section{PENDAHULUAN}

Semakin sempitnya lahan mengharuskan dimanfaatkannya tanah kurang subur seperti tanah ordo Ultisol. Tanah ordo merupakan salah satu jenis tanah kurang subur yang dimanfaatkan dalam bidang pertanian. Ultisol dicirikan oleh adanya akumulasi liat pada horison bawah permukaan sehingga mengurangi daya resap air dan meningkatkan aliran permukaan serta erosi tanah (Andalusia and Arabia 2016). Pemanfaatan bahan organik dari limbah sisa panen ini sangat efektif mengingat unsur hara tersebut bisa dimanfaatkan dan bisa membantu petani dalam mengurangi dosis penggunaan pupuk buatan. Oleh karena itu, praktek pertanian yang berwawasan lingkungan dengan memanfaatkan limbah hasil pertanian dapat mengatasi masalah pencemaran lingkungan, menambah kesediaan hara dan kehilangan unsur hara pada tanah.

Kehilangan unsur hara melalui terangkut panen yang terjadi di lahan sawah selain itu kebiasaan petani sehabis panen jerami ditumpuk dan langsung dibakar sehingga bisa menimbulkan dampak pencemaran udara serta mengganggu kehidupan organism. yang berada disekitarnya. Untuk mengatasinya dimanfaatkanlah jerami sebagai pupuk organik yang dikemas dalam bentuk kompos. Selain jerami tanaman padi juga menghasilkan sekam dari proses penggilingan yang juga bisa dimanfaatkan sebagai sumber unsur hara bagi tanaman padi itu sendiri. Sekam sebagai limbah penggilingan padi jumlahnya mencapai 20-23\% dari gabah. Sekam padi ini sangat potensial dijadikan biochar untuk menambah unsur hara pada tanaman. 


\section{METODE PENELITIAN}

Penelitian ini telah dilaksanakan di Kenagarian Sungai Abang Kecamatan Lubuk Alung Kabupaten Padang Pariaman dan analisis tanah dilakukan di Laboratorium Fakultas Teknik Lingkungan Universitas Andalas pada bulan Februari sampai Juli 2018. Penelitian ini menggunakan rancangan acak kelompok (RAK) yang terdiri dari 5 taraf perlakuan yaitu $0 \%$ Biochar sekam padi $+0 \%$ Kompos jerami padi $(\mathrm{O}), 100$ $\%$ Biochar sekam padi $+0 \%$ Kompos jerami padi (A), $75 \%$ Biochar sekam padi + $25 \%$ Kompos jerami padi (B), $50 \%$ Biochar sekam padi $+50 \%$ Kompos jerami padi (C) dan $25 \%$ Biochar sekam padi $+75 \%$ Kompos jerami padi (D). Data yang diperoleh disidik ragam dengan uji F, jika F hitung lebih besar dari F tabel maka dilanjutkan dengan uji BNT taraf $5 \%$. Biochar berasal dari sekam padi yang pembuatannya menggunakan tiang pembakaran, seperti yang dilakukan oleh (Maghdalena, Widiastuti, and Lantang 2017) sedangkann kompos dilakukan dengan masa pengomposan 4 minggu dengan bahan dasar jerami padi, pupuk kandang sapi serta EM-4. Biochar sekam

\section{HASIL DAN PEMBAHASAN}

\section{A. Pengamatan Tanah}

\section{Analisis Tanah Awal}

Tanah ordo Ultisol sebelum pemberian perlakuan memiliki kandungan unsur hara yang rata-rata rendah. Berdasarkan Tabel 1 tanah ordo Ultisol memiliki nilai $\mathrm{pH}$ agak masam sehingga ini juga berdampak terhadap ketersediaan padi $100 \%$ dan kompos jerami padi $100 \%$ setara dengan 10 ton/ha. Bahan tersebut ditaburkan dan diaduk rata dengan tanah (sesuai perlakuan) kemudian diinkubasi selama 4 minggu. Penanaman dilakukan setelah 4 minggu masa inkubasi inkubasi terhadap tanaman padi varietas Cisokan dengan jarak tanam $25 \mathrm{~cm} \mathrm{x} 25 \mathrm{~cm}$ dan benih pindah tanam umur 14 hari setelah semai dengan kondisi sawah macakmacak. Pemupukan yang dilakukan menggunakan pupuk buatan (Urea, TSP, $\mathrm{KCl})$ dengan $75 \%$ dari rekomendasi. Pengamatan tanah meliputi analisis tanah awal yaitu sebelum perlakuan diberikan, analisis tanah setelah inkubasi, dan analisis tanah akhir yaitu $\mathrm{pH}$ menggunakan metode elektroda gelas $\mathrm{pH}$ meter, Sulfur, N-total dengan metoda Kjeldhal, P-total dengan metoda Bray 2 dan untuk K-dd, Ca-dd, Mg-dd menggunakan metoda ammonium asetat sedangkan pengamatan yang dilakukan terhadap tanaman meliputi tinggi tanaman, jumlah anak total, jumlah anakan produktif dan bobot gabah per hektar.

unsur hara seperti $\mathrm{N}$-total dan $\mathrm{Ca}$-dd dalam kriteria sedang serta $\mathrm{K}$-dd dan $\mathrm{Mg}$ dd dalam kriteria rendah. Untuk nilai Ptotal pada tanah ordo Ultisol ini tergolong sangat tinggi. Analis tanah awal sebelum pemberian perlakuan dapat dilihat pada Tabel 1.

Tabel 1. Analisis Tanah Ordo Ultisol Sebelum Pemberian Perlakuan Biochar Sekam dan Kompos Jerami Padi

\begin{tabular}{cccc}
\hline Parameter Pengamatan & Satuan & Nilai & Kriteria \\
\hline pH & & 6,190 & Agak Masam \\
N-total & $\%$ & 0,420 & Sedang \\
P-total & ppm & 275,781 & Sangat tinggi \\
K-dd & me 100 gr tanah & 0,191 & Rendah \\
Ca-dd & me $/ 100$ gr tanah & 6,580 & Sedang \\
Mg-dd & me $/ 100$ gr tanah & 0,980 & Rendah \\
$\mathrm{S}$ & $\%$ & 0,122 & \\
\hline
\end{tabular}


Tabel 1 menunjukkan nilai posfor pada tanah Ultisol tergolong sangat tinggi. Tingginya kandungan posfor dalam tanah dikarenakan kebiasaan dalam menggunakan pupuk $P$ dalam jumlah yang berlebih sehingga terjadi pengendapan di lapisan bawah tanah. Ketersediaan posfor pada tanah sawah diakibatkan oleh beberapa mekanisme Watanabe dan Roger (1985) cit Gusnidar (2007) yaitu (1) terjadinya gangguan mekanika tanah yang terjadi pada saat pengolahan tanah, (2) difusi dari tanah yang terjadi akibat adanya adsorbsi dan desorbsi orthofosfat dari sedimen yang tergantung pada jumlah relative $\mathrm{P}$ dalam larutan tanah dan (3) aktifitas plankton dan fauna yang terjadi

\begin{tabular}{|c|c|c|c|}
\hline \multirow{2}{*}{\multicolumn{2}{|c|}{ Perlakuan }} & \multicolumn{2}{|c|}{$\mathrm{pH}$} \\
\hline & & Inkubasi & Panen \\
\hline $0 \%$ & Biochar Sekam Padi $+0 \%$ Kompos Jerami Padi & 6,10 & 6,30 \\
\hline $100 \%$ & Biochar Sekam Padi $+0 \%$ Kompos Jerami Padi & 6,16 & 6,28 \\
\hline $75 \%$ & Biochar Sekam Padi $+25 \%$ Kompos Jerami Padi & 6,44 & 6,90 \\
\hline $50 \%$ & Biochar Sekam Padi $+50 \%$ Kompos Jerami Padi & 6,36 & 6,90 \\
\hline $25 \%$ & Biochar Sekam Padi $+75 \%$ Kompos Jerami Padi & 6,13 & 6,68 \\
\hline
\end{tabular}

Nilai pH tanah Ultisol biasanya akan meningkat akibat dari penggenangan dan cenerung terus naik atau turun sampai $\mathrm{pH}$ 7 (netral). Pada perlakuan $0 \%$ Biochar Sekam Padi $+0 \%$ Kompos Jerami Padi terjadi penurunan nilai $\mathrm{pH}$ dibandingkan dari tanah awal (Tabel 1). Penurunan $\mathrm{pH}$ pada awalnya disebabkan oleh adanya akumulasi $\mathrm{CO}_{2}$ dan terbentuknya asamasam organik. Kenaikan $\mathrm{pH}$ tanah berikutnya ini bersamaan dengan proses reduksi dan ditentukan oleh $\mathrm{pH}$ tanah awal, jenis dan kadar komponen tanah yang teroksidasi serta macam dan kandungan bahan orgnanik (Djakasutami dsn Djakamihardja, 1990 cit Gusnidar, 2007). Berdasarkan penelitian (Zhao et al. 2016) mendapatkan pemberian biochar yang ke tanah dapat berpotensi untuk mengurangi bioavailabilitas, pelindian logam berat dan polutan organik dalam tanah melalui adsorpsi dan reaksi fisikokimia. Selain itu biochar juga mempunyai sifat basa yang dapat akibat kemungkinan berpindahnya $\mathrm{P}$ dari tanah ke genangan air akibat perubahan yang aktif oleh mikroorganisme tanah sawah.

\section{pH Tanah Ordo Ultisol}

Pemberian biochar sekam dan kompos jerami padi terhadap tanah ordo Ultisol pada saat setelah inkubasi belum menampakkan kenaikan $\mathrm{pH}$ dan berdasarkan kriteria masih kategori sangat masam $(6,10-6,44)$ dan pada saat setelah panen baru terjadi peningkatan terhadap pH berdasarkan kriteria dikategorikan netral. Nilai $\mathrm{pH}$ tanah ordo Ultisol setelah pemberian biochar sekam dan kompos jerami padi disajikan pada Tabel 2. meningkatkan $\mathrm{pH}$ tanah dan berkontribusi dalam menstabilkan ketersediaan logam berat dalam tanah.

\section{P-total Tanah Ordo Ultisol}

Ketersediaan hara Posfor akibat pemberian biochar sekam dan kompos jerami padi juga mengalami peningkatan.

Tabel 3 menunjukkan posfor pada tanah meningkat dengan penambahan biochar sekam dan kompos jerami padi. Tingginya kandungan posfor disumbangkan oleh bahan organic yang bersumber dari biochar dan kompos. Biochar sekam padi yang diberikan kedalam tanah selain dapat menyumbangkan unsure hara ternyata juga mampu mengikat unsure hara yang disumbangkan oleh kompos jerami padi. Berdasarkan hasil penelitian (Tamtomo et al. 2015) kompos jerami padi memberikan dampak positif terhadap peningkatan produksi ubijalar tetapi juga dapat meningkatkan kandungan unsur $\mathrm{N}, \mathrm{P}$ dan $\mathrm{K}$, selain itu juga meningkatkan 
kandungan bahan organik tanah yang mampu memperbaiki sifat fisik tanah.

Tabel 3. P-total Tanah Ordo Ultisol Setelah Inkubasi dan Setelah Panen

\begin{tabular}{|c|c|c|c|}
\hline & & & \\
\hline & Perlakuan & Inkubasi & Panen \\
\hline $0 \%$ & Biochar Sekam Padi $+0 \%$ Kompos Jerami Padi & 248,876 & 300,241 \\
\hline $100 \%$ & Biochar Sekam Padi $+0 \%$ Kompos Jerami Padi & 244,672 & 298,920 \\
\hline $75 \%$ & Biochar Sekam Padi $+25 \%$ Kompos Jerami Padi & 455,711 & 531,330 \\
\hline $50 \%$ & Biochar Sekam Padi $+50 \%$ Kompos Jerami Padi & 455,711 & 537,430 \\
\hline $25 \%$ & Biochar Sekam Padi $+75 \%$ Kompos Jerami Padi & 438,054 & 536,271 \\
\hline
\end{tabular}

N-total dan Sulfur Tanah Ordo Ultisol

N-total dan Sulfur pada tanah mengalami peningkatan dengan disajikan pada Tabel 4.

Tabel 4. N-total dan Sulfur Tanah Ordo Ultisol Setelah Inkubasi dan Setelah Panen

\begin{tabular}{|c|c|c|c|c|c|}
\hline & \multirow{3}{*}{ Perlakuan } & \multicolumn{2}{|c|}{ N-total } & \multicolumn{2}{|c|}{ Sulfur } \\
\hline & & Inkubasi & Panen & Inkubasi & Panen \\
\hline & & & & & \\
\hline $0 \%$ & Biochar Sekam Padi $+0 \%$ Kompos Jerami Padi & 0,628 & 1,849 & 0,174 & 0,310 \\
\hline $100 \%$ & Biochar Sekam Padi $+0 \%$ Kompos Jerami Padi & 0,620 & 1,776 & 0,185 & 0,286 \\
\hline $75 \%$ & Biochar Sekam Padi $+25 \%$ Kompos Jerami Padi & 1,183 & 2,886 & 0,285 & 0,367 \\
\hline $50 \%$ & Biochar Sekam Padi $+50 \%$ Kompos Jerami Padi & 1,553 & 1,683 & 0,229 & 0,254 \\
\hline $25 \%$ & Biochar Sekam Padi $+75 \%$ Kompos Jerami Padi & 1,210 & 1,654 & 0,266 & 0,315 \\
\hline
\end{tabular}

Nitrogen dan Sulfur pada tanah ordo Ultisol juga mengalami peningkatan, bahkan setelah panenpun tetap tinggi ketersediaannya. Kandungan Nitrogen dan Sulfur ini dapat dimanfaatan untuk musim tanam berikutnya. Menurut (Steiner 2007), penggunaan biochar sekam merupakan bahan alternatif untuk perbaikan kesuburan tanah sekaligus untuk perbaikan lingkungan yang murah, berkelanjutan, dan ramah lingkungan. Biochar dapat memperbaiki sifat kimia, fisik, dan biologi tanah dan penggunaan biochar sekam dapat mengurangi kehilangan Nitrogen.

K-dd, Ca-dd dan Mg-dd Tanah Ordo Ultisol

Unsur Kalium, kalsium dan magnesium merupakan unsur hara yang sangat penting selain nitrogen. Apabila tanaman kekurangan unsur hara ini bisa berdampak ke pertumbuhan tanaman, salah satu contoh adalah kekurangan unsur Kalium bisa mengakibatkan tanaman mudah rebah. Penggunaan biochar sekam dan kompos jerami padi dapat meningatkan ketersediaan ketiga unsur tersebut. Hal ini dapat dilihat pada Tabel 4.

Biochar sekam memiliki kemampuan penyediaan unsur $\mathrm{K}$ tertinggi sekitar $0,90 \%$ begitu juga memberikan nilai KTK yang tertinggi yaitu 29,27 me/100 g (Nurida and Muchtar 2017). Oleh karena itu, pada pengamatan setelah panen rata-rata nilai $\mathrm{K}$-dd, $\mathrm{Ca}-\mathrm{dd}$ dan $\mathrm{Mg}$ dd mengalami peningkatan. Kationkation merupakan sumber unsur hara sehingga dapat mengoptimalkan pertumbuhan tanaman. 
Tabel 4. K-dd, Ca-dd dan Mg-dd Tanah Ordo Ultisol Setelah Inkubasi dan Setelah Panen

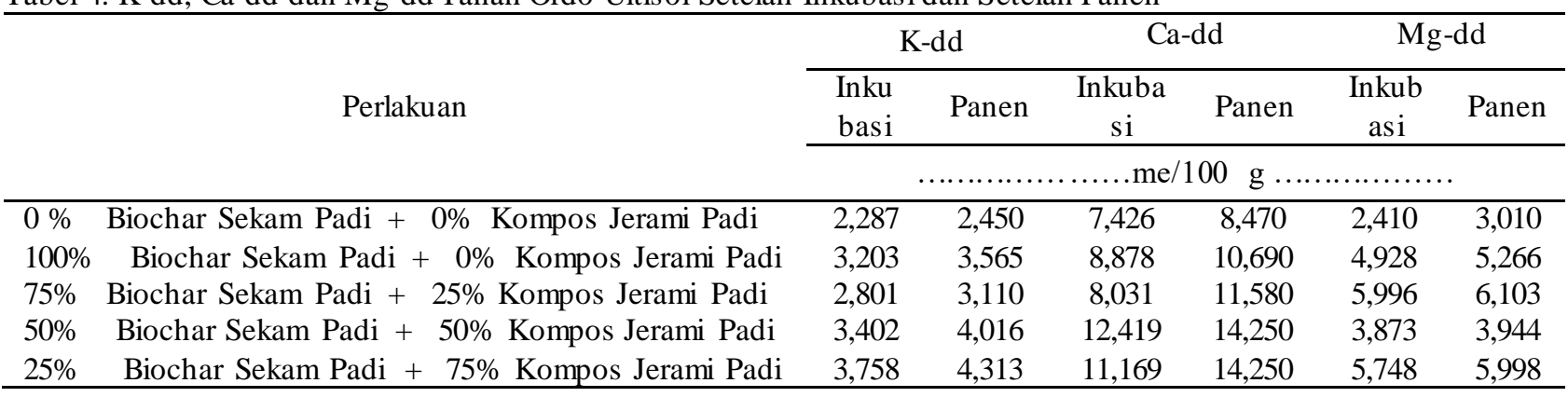

\section{B. Pengamatan Tanaman}

Tinggi Tanaman dan Jumlah Anakan Total

Parameter pengamatan terhadap tanaman padi meliputi tinggi tanaman, jumlah anakan total dan jumlah anakan produktif. Untuk parameter tinggi tanaman dan jumlah anakan total berdasarkan hasil analisis sidik ragam menunjukkan bahwa kombinasi dosis biochar sekam padi dan kompos jerami padi tidak berbeda nyata. Tinggi tanaman dan jumlah anakan total tanaman padi dapat dilihat pada Tabel 5.

Tabel 5. Pengaruh Biochar Sekam dan Kompos Jerami Padi Terhadap Tinggi Tanaman dan Jumlah Anakan Total

\begin{tabular}{|c|c|c|c|}
\hline & Perlakuan & $\begin{array}{l}\text { Tinggi Tanaman } \\
\text { (cm) }\end{array}$ & $\begin{array}{c}\text { Jumlah Anakan } \\
\text { Total } \\
\text { (rumpun) } \\
\end{array}$ \\
\hline $0 \%$ & $0 \%$ Kompos Jerami Padi & 91,531 & 28,312 \\
\hline $100 \%$ & Biochar Sekam Padi $+0 \%$ Kompos Jerami Padi & 91,750 & 28,000 \\
\hline $75 \%$ & Biochar Sekam Padi $+25 \%$ Kompos Jerami Padi & 96,094 & 31,438 \\
\hline $50 \%$ & Biochar Sekam Padi $+50 \%$ Kompos Jerami Padi & 88,031 & 27,813 \\
\hline $25 \%$ & Biochar Sekam Padi $+75 \%$ Kompos Jerami Padi & 90,625 & 27,063 \\
\hline
\end{tabular}

Tabel 5 menjelaskan tidak adanya perbedaan terhadap tinggi tanaman dan jumlah anakan total terhadap tanaman yang diberikan biochar sekam dan kompos jerami padi dengan yang tidak diberikan biochar sekam dan kompos jerami padi. Pemberian biochar sekam dan kompos jerami padi dengan masa inkubasi 2 minggu belum mampu menyediakan unsur hara secara optimal sehingga belum dapat dimanfaatkan oleh tanaman padi untuk pertumbuhannya.

Biochar sekam dan kompos jerami padi yang diberikan ternyata belum mampu menunjukan pengaruh yang signifikan terhadap parameter tinggi tanaman dan jumlah anakan total. Hal ini dikarenakan sumber bahan organik yang diberikan belum mengalami dekomposisi secara sempurna sehingga unsur hara lambat tersedia dan belum dapat dimanfaatkan oleh tanaman padi, terutama bahan organik yang bersumber dari jerami padi. Meskipun dalam penelitian telah dilakukan proses pengomposan ternyata membutuhkan waktu yang lebih aga dapat tersedia unsur haranya. Sejalan dengan pendapat Makarim, Sumarno dan Suryanto (2007) cit (Tamtomo et al. 2015) jerami padi membutuhkan waktu 3-4 bulan setelah panen agar dapat terdekomposisi secara sempurna.

\section{Jumlah Anakan Produktif}

Tabel 6 menunjukkan berdasarkan hasil analisis sidik ragam menunjukkan bahwa pengaruh pemberian biochar sekam dan kompos jerami padi berbeda nyata terhadap jumlah anakan produktif. Jumlah anakan tertinggi ditunjukkan pada perlakuan $75 \%$ Biochar Sekam Padi + 
25\% Kompos Jerami Padi dengan hasil 29,940 anakan.

Perbedaan jumlah anakan terjadi karena tanaman padi telah dapat memanfaatkan penggunaan bahan organik yang diberikan berupa biochar sekam dan kompos jerami padi. Biochar yang diberikan telah mampu membantu di dalam penyerapan unsur hara salah satunya yang disumbangkan oleh kompos jerami padi. Salah satu peran dari biochar selain bisa memperbaiki sifat kimia dari tanah ternyata mampu mengefektifkan pemanfaatan pemupukan, dengan cara mengikat hara pada saat terjadi kelebihan hara dan melepaskan hara pada saat tanaman membutuhkan (slow release), sehingga bisa mencegah dari keracunan hara (terutama hara mikro) dan kekurangan hara. Biochar memiliki kelebihan dibandingkan bahan organik lainnya yaitu lebih persisten dalam tanah sehingga semua manfaat yang berhubungan dengan perbaikan kesuburan tanah dapat lebih optimal dimanfaatkan, sementara pupuk organik mengalami pembusukan yang mengemisikan gas berupa metana (Gani 2009).

Tabel 6. Pengaruh Biochar Sekam dan Kompos Jerami Padi Terhadap Jumlah Anakan Produktif Padi (Oryza sativa)

\begin{tabular}{lllc}
\hline \multicolumn{2}{c}{ Perlakuan } & $\begin{array}{c}\text { Jumlah Anakan Produktif } \\
\text { (rumpun) }\end{array}$ \\
\hline 0 & $\%$ & Biochar Sekam Padi $+0 \%$ Kompos Jerami Padi & $26,130^{\mathrm{a}}$ \\
$100 \%$ & Biochar Sekam Padi $+0 \%$ Kompos Jerami Padi & $26,690^{\mathrm{a}}$ \\
75 & $\%$ & Biochar Sekam Padi $+25 \%$ Kompos Jerami Padi & $29,940^{\mathrm{b}}$ \\
50 & $\%$ & Biochar Sekam Padi $+50 \%$ Kompos Jerami Padi & $26,000^{\mathrm{a}}$ \\
25 & $\%$ & Biochar Sekam Padi $+75 \%$ Kompos Jerami Padi & $25,060^{\mathrm{a}}$ \\
\hline
\end{tabular}

Keterangan : angka-angka yang diikuti oleh huruf kecil yang sama berbeda tidak nyata menurut BNT taraf $5 \%$

\section{Bobot Gabah Per Hektar}

Pemberian biochar sekam dan kompos jerami padi terhadap bobot gabah per hektar menunjukkan hasil yang berbeda nyata. Hasil tertinggi diperoleh pada perlakuan $75 \%$ biochar sekam padi + $25 \%$ kompos jerami padi. Semakin lama waktu biochar sekam dan kompos jerami padi berada di dalam tanah menciptakan kondisi lingkungan yang baik untuk pertumbuhan tanaman termasuk ketersediaan unsur hara. Bobot gabah dapat dilihat pada Tabel 7

Tabel 7. Pengaruh Biochar Sekam dan Kompos Jerami Padi Terhadap Bobot Gabah Per Plot dan Bobot Gabah Per Hektar Tanaman Padi (Oryza sativa)

\begin{tabular}{ccccc}
\hline \multicolumn{2}{c}{ Perlakuan } & $\begin{array}{c}\text { Bobot Gabah Per Plot } \\
(\mathrm{kg})\end{array}$ & $\begin{array}{c}\text { Bobot Gabah Per } \\
\text { Hektar } \\
\text { (ton) }\end{array}$ \\
\hline 0 & $\%$ & Biochar Sekam Padi $+0 \%$ Kompos Jerami Padi & $2,205^{\mathrm{a}}$ & $5,512^{\mathrm{a}}$ \\
$100 \%$ & Biochar Sekam Padi $+0 \%$ Kompos Jerami Padi & $2,719^{\mathrm{b}}$ & $6,798^{\mathrm{b}}$ \\
75 & $\%$ & Biochar Sekam Padi $+25 \%$ Kompos Jerami Padi & $3,295^{\mathrm{d}}$ & $8,238^{\mathrm{d}}$ \\
50 & $\%$ & Biochar Sekam Padi $+50 \%$ Kompos Jerami Padi & $2,871^{\mathrm{c}}$ & $7,178^{\mathrm{c}}$ \\
$25 \%$ & Biochar Sekam Padi $+75 \%$ Kompos Jerami Padi & $2,740^{\mathrm{c}}$ & $6,849^{\mathrm{c}}$ \\
\hline
\end{tabular}

Keterangan : angka-angka yang diikuti oleh huruf kecil yang sama berbeda tidak nyata menurut BNT taraf $5 \%$

Pemberian biochar sekam dan semakin tersedia pula unsur-unsur hara kompos jerami padi dapat meningkatkan makro. Unsur hara makro ini yang nilai pH tanah ordo Utisol (Tabel 2). dibutuhkan oleh tanaman untuk Semakin meningkat nilai pH maka pertumbuhannya seperti Nitrogen, Posfor, 
Kalium, Kalsium, Magnesium dan Sulfur. Biochar yang berasal dari pembakaran memiliki memiliki nilai $\mathrm{pH}$ yang tinggi, C-organik tinggi dan luas permukaan yang tinggi. Sifat-sifat yang dimiliki biochar tersebut menyebabkan biochar memiliki daya retensi hara yang tinggi sehingga dapat mengurangi pencuciaan hara. Hal ini membuat unsur hara yang tersedia di

\section{KESIMPULAN}

Penggunaan biochar dan kompos jerami padi mempengaruhi pertumbuhan dan produksi tanaman padi yang terlihat pada perlakuan $75 \%$ Biochar sekam padi +25 $\%$ Kompos Jerami dengan jumlah anakan produktif sebanyak 29 anakan dan

\section{UCAPAN TERIMA KASIH}

Terima kasih penulis ucakan kepada Allah SWT yang telah memberikan rahmat kesehatan sehingga penulis dapat melaksanakan penelitian ini dengan baik, terima kasih kepada Direktorat Riset dan Pengabdian Masyarakat, Direktorat Jenderal Penguatan Riset dan Pengembangan Kementrian Riset, Teknologi dan

\section{DAFTAR PUSTAKA}

Andalusia, Bunga, and Teti Arabia. 2016. 'Karakteristik Tanah Ordo Ultisol Di Perkebunan Kelapa Sawit PT. Perkebunan Nusantara I ( Persero ) Cot Girek Kabupaten Aceh Utara." Jurnal Kawista 1(1): 45-49.

Gani, Anischan. 2009. "Potensi Arang Hayati ' Biochar ' Sebagai Komponen Teknologi Perbaikan Produktivitas Lahan Pertanian." Jurnal Iptek Tanaman Pangan 4(1): 33-48.

Gusnidar. 2007. Budidaya dan Pemanfaatan Thitonia diversifolia Untuk Menghemat Pemupukan N, P dan K Padi Sawah Intensifikasi. dalam tanah yang berasal dari kompos jerami padi dapat dimanfaatkan oleh tanaman padi sehingga produksi dapat meningkat. Menurut (Novak et al. 2009) Biochar tidak hanya memiliki kemampuan retensi yang tinggi tetapi juga mengandung unsur hara yang dapat diserap oleh tanaman.

produksi tanaman padi sebanyak 8,238 ton/ha.

Penggunaan biochar sekam dan kompos jerami padi mampu menyediakan hara pada tanah ordo Ultisol yang ditunjukkan dengan meningkatnya $\mathrm{pH}, \mathrm{N}$, $\mathrm{P}, \mathrm{K}, \mathrm{Ca}, \mathrm{Mg}$ dan $\mathrm{S}$.

Pendidikan Tinggi yang telah membiayai penelitian ini sesuai dengan kontrak penelitian Nomor SP DIPA042.06.1.401516/2018 Tanggal 5 Desember 2017 serta kepada LPPM Universitas Tamansiswa Padang yang telah banyak membantu peneliti dalam melaksanakan penelitian.

Disertasi Program Pascasarjana. UNAND.

Maghdalena, Maria, Diana Widiastuti, and Bonny Lantang. 2017. "Pelatihan Pembuatan Biochar Dari Limbah Sekam Padi Menggunakan Metode Retort Kiln ( Training on Biochar Production from Rice Husk Using Retort Kiln Method )." Jurnal Ilmiah Pengabdian Kepada Masyarakat 3(2): 129-35.

Mawardiana, Sufardi, and Husen Edi. 2013. 'Pengaruh Residu Biochar Dan Pemupukan NPK Terhadap Sifat Kimia Tanah Dan Pertumbuhan Serta Hasil Tanaman Padi Musim Tanam 
Ketiga." Jurnal Manajemen Sumber Dayalahan 2(1): 255-60.

Novak, Jeffrey M. et al. 2009. "Impact of Biochar Amend ment on Fertility of a Southeastern Coastal Plain Soil." Soil Science 174(2): 105-12.

Nurida, Neneng Laela, and Muchtar. 2017. "Pemanfatan Biochar Kulit Buah Kakao Dan Sekam Padi Untuk Meningkatkan Produktivitas Padi Sawah Di Ultisol Lampung." Jurnal Pengkajian dan Pengembangan Teknologi Pertanian 20(1): 69-80.

Steiner, Christop. 2007. "Soil Charcoal Amandements Maintain Soil Fertility And Establish Carbon Sink-Research and Prospects." Soil Ecology Research Developments: 1-6.

Tambunan, Sonia, Bambang Siswanto, and Eko Handayanto. 2014. "Pengaruh Aplikasi Bahan Organik Segar Dan Biochar Terhadap Ketersediaan P Dalam Tanah Di Lahan Kering Malang Selatan." Jurnal Tanah dan Sumberdaya Lahan 1(1): 85-92. http://jtsl.ub.ac.id.

Tamtomo, F, Sri Rahayu, Agus Suyanto, and Fakultas Pertanian. 2015. "Pengaruh Aplikasi Kompos Jerami Dan Abu Sekam Padi Terhadap Produksi Dan Kadar Pati Ubijalar." 12(2): 1-7.

Zhao, Jiankun et al. 2016. "Effects of Biochar Amendment on Soil Thermal Properties in the North China Plain." Soil Science Society of America Journal 80(5): 1157-66. 